\title{
Biorhetorics: An introduction to applied rhetoric
}

\author{
Stephen Pain \\ University of East Anglia (resident in Paris) \\ c/o Elena Blinkova, 9 Square Desaix, Paris 75005, France \\ e-mail: st3pen@hotmail.com
}

\begin{abstract}
This paper is an introduction to the new field of biorhetorics. Biorhetorics is an applied form of rhetoric that evolved from the study of classical rhetoric, particularly Aristotelian. The author illustrates the stages of development necessary for the creation of a species-specific rhetoric: by (1) formalising rhetoric so as to create a functional rhetoric, (2) then reducing this to a symbolic rhetoric that can be used in conjunction with the collected data of an organism's Umwelt (including its genome) to form (3) a species-specific rhetoric. The paper draws upon the latest research on bacterial and viral communication to show the possibilities of biorhetorics. In the course of discussing the nature of biorhetorics the author distinguishes it from argumentation theory and rhetoric/s of biology, and positions alongside other fields used in the life sciences such as biosemiotics, information theory, game theory, etc.
\end{abstract}

In 2001, Kalevi Kull published a short article on the new discipline of biorhetorics (Kull 2001). Here, I would like to avail myself of an opportunity to respond and set out something about my own theory of the discipline.

\section{Biorhetorics and rhetoric/s of biology}

Biorhetorics is an applied form of rhetoric for actual usage in the life sciences, while rhetoric/s of biology is in the main a study of rhetoric that is both analytical and deconstructive in nature. Rhetoric/s of biology is political and concerned with the practices of scientists; the inequalities made evident in their usage of rhetoric. In the develop- 
ment of my own conception of biorhetorics I have sought to create a rhetoric that can be applied to universal communication situations involving all forms of life. There have been several stages to this development, firstly creating a functional rhetoric from classical rhetoric, secondly moving onto a symbolic rhetoric, then thirdly creating a species specific rhetoric based on the Umwelt of the organism or audience in question. In my primary case study I have used a virus (the bacteriophage M13) and its host (the Escherichia coli F-pilus) since they represent a real challenge as their rhetorical competency and cognitive levels are extremely low and obviously controversial. However once the reader realises that biorhetorics can be used with such lower forms of life, they will then see the potential for all life forms regardless of their state of evolution.

\section{Classical rhetoric}

Rhetoric belongs to a classical triumverate of Aristotelian argumentation, namely, demonstrative, dialectical, and rhetorical. Of these three rhetorical argumentation differs from the others because its objective, status of premisses, deduction are all rooted firmly in the cogent and the audience is integral to its usage (see Eemeren et al. 1987: 59). Rhetoric can be defined as the art/techne of persuasive eloquent speech/writing. In traditional rhetoric one requires the rhetor or orator to be an articulate human capable of penmanship. I have argued below that competency runs along an experiential and evolutionary axis.

\subsection{The branches of oratory}

There are three traditional branches, these being: genus iudicale (forensic), genus deliberativum (legislative/political), genus demonstativum or epideictic (demonstrative). Each of these branches according to Aristotle is associated with a particular time (past, present, future), has a particular purpose with a binary structure: to accusel defend, to exhort/defend and to praise/blame. Each of the branches has particular topics or topoi drawn from the canon of invention. Of the three branches, the demonstrative or epideictic is capable of being pared down into a general functional rhetoric as the other two are more rooted in human society. 


\subsection{Five canons of rhetoric}

Rhetoric is traditionally subdivided into the five canons, of invention (inventio), arrangement (dispositio), style (elocutio), memory (amamnesis), and delivery (actio). Invention is the preparation for the speech and involves seeking suitable topoi or topics drawn from a classical database of topics of invention (i.e., definition, relationship, etc.). Arrangement is the order or structure of the speech, classically an exordium or introduction using ethos to appeal to the audience, a partitio or division which is an outline of the speech, a confirmatio or proof based upon logos or logical reasoning, refutatio or refutation, then finally a peroratio that uses the persuasive appeal of pathos. Style determines the nature of the narrative and is inextricably linked to the nature and composition of the audience. There are levels of style, high, middle and low, and vices and virtues to the use of style. The choice of level is important, for example use of a high style might offend one kind of audience. Memory is important in rhetoric because it aids the composition, the memory of a figure or a classical line used in a previous kairos "context" could make all the difference in a speech. The speech is articulated and delivered to an audience, a poor performance can ruin a good speech, and subsequently many rhetoricians have devoted energy to creating manuals of how to deliver a speech. The Victorians had many popular books that detailed the kind of voice and body language used in making a good speech. ${ }^{1}$

\subsection{Proofs and argumentation}

In the development of an argument, the rhetor or orator needs to provide evidence or proof to an audience that his argument is a good one. Unlike logic which requires strict adherence to a set of rules, rhetoric can deviate from true logical reasoning, as its teleology is a good rather than a truth. To persuade an audience to change their minds about a particular subject, the rhetor can draw upon a whole array of figures of reasoning and proofs, but one which for the purposes of biorhetorics is of greater interest, is the enthymeme, a figure that uses syllogistic reasoning with a suppressed premise to be

${ }^{1}$ For this section I am indebted to Gideon O. Burton, Silva Rhetoricae (http: //humanities.bye.edu/rhetoric), Brigham University (1996-2002). 
supplied by an audience. ${ }^{2}$ Biorhetorics is closer to demonstration than Perelman's (1982) conception of argumentation in the following: it uses calculation, mathematical symbols and syllogism albeit enthymetic, and has non-human or impersonal elements to it. But it does also emphasise and begin with the notion of audience agreement, has a sense of communality, and aims toward a good.

\subsection{Macrostructural and microstructural figures}

In introductions to rhetoric, critics often divide rhetoric either synoptically or into trees. One moves from the large structure to the microscopic. From the tree, to the branch, the twigs, and to the flowers (see Burton, footnote 1). According to Georges Molinié author of the Dictionnaire de rhétorique (1992), macrostructural figures would include larger narrative sequences such as an allégorie and ironie, while the microstructural would be figures to do with smaller narrative sequences, such as hypozeuxe, metonymie, etc. In the development of a functional and symbolic rhetoric it would be important to insist upon a hierarchical structure, even if in some cases the figures are mavericks that cross over.

\subsection{Kairos, decorum and audience}

The kairos is the context of the speech or the situation; it is important for deciding the type of speech required. If, for example, it is a speech after the September the 11th 2001 in front of New York firefighters it would require some mention of their colleagues deaths by way of respect and to win sympathy for the speech. The apt manner and delivery of the speech, the decorum, changes according to the audience, so it might be possible to use humour of a more robust and chauvinistic form in front of the firemen than another audience, indeed Presidents often make use of homosocial bonding to get their policies across to predominantly male groups, such as the armed forces and emergency services. Kairos can be as in biosemiotics equated with the Umwelt of a species (Uexküll 1973).

${ }^{2}$ See comprehensive bibliography in Poster, Carol 2002. The enthymeme: An interdisciplinary bibliography of critical studies. The Journal for the Study of Rhetorical Criticism of the New Testament (http: //rhetjournal.uor.edu/Enth.html). 


\section{Functional rhetoric: Preamble}

Given the enormity and scope of classical rhetoric the project of reducing it to a functional rhetoric seems daunting, nevertheless I feel it is necessary as I believe rhetoric like its sisters, logic, and dialectic has great potential, even more so in the age of computer communication.

Rhetoric is vulgarly seen as a superior form of sophistry, a prejudice that dates back to Plato and the death of Socrates, or as a pedagogical tool useful in the composition of dreaded essays or at the writing up stage of a thesis, rarely is it seen as something that might be useful in science proper. Over the years variants of logic have prospered and some are used in animal behaviour studies, an area in which biorhetorics will be of great use, such as semiotics, pragmatics, cybernetics, information theory, game theory, cost-benefit analysis and so on. What however is not so obvious is that in the course of the development of these variants of logic, rhetoric played a significant part. Charles Peirce was greatly interested in rhetoric and his conception of semiotics owes a lot to his studies of rhetoric. Indeed, in the entire history of modern logic one realises that logicians nudged closer and closer to the territory of rhetoric. This is not surprising because Aristotle, the father of natural sciences and logic, insisted upon an intimacy between logic and rhetoric and wanted rhetoric to have the same rigor. His book on rhetoric represented a "platonic" counterattack against the school of Isocrates which was more popular than the academy and had strongly featured rhetoric in its curriculum. Aristotle gave rhetoric a firm logical underpinning, and though often he contradicts himself or is unnecessarily repetitive, the basis of a functional rhetoric can be discovered in his writings.

\subsection{Functional rhetoric: Definitions}

In the development of a functional rhetoric, those in the humanities, especially those in the departments of classical rhetoric and speech composition will question how is it possible to have a non-human rhetor/audience? Surely rhetoric the art/techne of speech requires that the rhetor to be a penholding, articulate mammal, and that the audience be competent to read or listen to the speech and respond in an intelligent manner. An objection voiced by friend of mine was that how can one argue with a dog? Wave a bone and say sit down? The 
divide between instinctive and non-instinctive behaviour and between verbal and non-verbal communication is too great. This however is a misunderstanding of what biorhetorics is about, I do not intend for scientists to read out Winston Churchill's speeches to Wister Lab rats. But this notion of competency and definition of what an audience is, can be a productive springboard.

\subsection{The audience is life}

Contemporary definitions of life have moved the goal posts, so much that one could almost bring in crystals as a life form. As definitions of life are contingent upon the science or prevailing episteme of the day, it would seem far better to see life on an evolutionary continuum or axis. The divide between non-life and the divide between instinctive and non-instinctive behaviour should also seen on an evolutionary and experiential axis.

\subsection{Rhetorical competency}

Let us consider by way of a case study a simple life form a helical caspid like a filamentous phage the bacteriophage $M 13$ that uses host cell machinery for replication, in this case the bacteria Escherichia coli F-pilus. How could we use rhetoric in this case, and how on earth could one talk of rhetorical competency? The agent in the rhetorical act uses language to move an audience. The success of the argument used is dependent upon a shared linguistic and cognitive knowledge base. Perelman (1982) with an eye to legal persons, requires the audience to be reasonable and competent people. The efficiency of the argument increases and decreases according to whether it is understood, or indeed received. It would be rather Monty Pythonesque to sit in front of a microscope slide with a few thousand M13 as an audience and expect something to happen. But on the other hand if that audience were higher up along the evolutionary axis, one might in a moment of anthropomorphism be persuaded that it is possible to communicate and argue effectively with a group of dogs or chimpanzees: on an emotional rather than a neological level people believe that they do communicate and sometimes argue with animals. At what point can we say that an audience is competent, and what are the tests? We could as has been done already — see analogous rhetorical 
systems in animal communication and discuss competency in terms of those systems - but this would be different from what I had in mind. What we can do is create something akin to B. F. Skinner's room, Jakob von Uexküll's room, and in this room we could put different combinations of rhetors and audiences of higher, middle, and lower cognitive levels. If we use simple set theory we will then realise that there are fields of competency and comprehensibility that are determined by the cognitive base of each party, and that different percentages of the argument are understood. For example if the rhetor and audience are from the same class background, use the same language, are of the same gender, then it will be easier to move that audience from their current position or course of action to a desired one. If on the other hand the audience is Italian and the rhetor is English there might be problems, only part of the verbal argument could be understood, and a fair percentage of the nonverbal. Still more difficult would be an aboriginal audience as their cultural templates and values are different, but even here, we can say that there are cardinal emotions that can be read by all members of humanity (Darwin 1872) and even here we can talk of a degree of rhetorical competency. We can then move across the species barrier to animals that are instinct driven, and still we can see that at the stage of delivery, the tone of the voice and the nonverbal language can be followed by domestic animals such as cats and dogs. Without being ridiculous we could descend down this line all the way to the simplest form of life like the bacteriophage I mentioned above. Each life form can be said to have a degree of competency, one which would clearly not satisfy the traditionalist or those hell-bent on language game rules: Austin would talk of infelicities. Nor would the cognitive and neuroscientists be pleased at the notion of according lower life forms the cognitive skills to be able to follow a rhetorical argument. ${ }^{3}$ But as with the question of cognition, rhetorical competency can be said to be dependent upon the level of the rhetor and audience. It is perfectly acceptable to talk of a continuum of rhetorical competency, just as we talk of an axis of language evolution, or as Konrad Lorenz does the phylogenetic ascent of human rituals such as peace pipe smoking from established habits and rituals in instinctual behaviour (Lorenz 1970: $67,73,74)$.

${ }^{3}$ I would like to have elaborated on the problem of Chomsky's language organ or faculty and the nature of the competent rhetor/audience. 


\section{Towards a species-specific rhetoric}

If we wanted to address the problem of rhetorical competency we could say the problem lay not in the audience, but in the rhetor, it is up to the rhetor to understand the kairos and decorum connected with his/her particular audience. If that audience is a bacteriophage, then he must understand that organism's mode or system of communication. How does a bacteriophage communicate and understand its environment? How does it move to the E. coli, and is there any communication between them? Both organisms are on a low level cognitive plane, but both within their biological parameters are capable of quite sophisticated modes of inter/intra species communication. They are aware of their immediate environment, their individual state, able to recognise their immediate neighbours and cooperate and coordinate, show altruistic behaviour, locate predators/prey and hosts and communicate with them (Primio et al. 2000). The bacteriophage through molecular recognition seeks out its host for attachment at the F-pilus end. The genes responsible for this and the complex of proteins involved have been identified ( $g 3 p$ and $g 6 p$ ), since the bacteriophage has played an important role in genetics and in technologies associated with it. The $M 13$ has ten essential genes (Cann 2001). There has been a great deal of work done on the communication systems of the E. coli too. It has a flagella with a motor and this is linked to the stresses of stimulation in its environment. Cellular proteins responsible for transduction of chemical signals and coordinate the flagella movement into a tumbling and nontumbling mode have been identified as CheA, CheW, CheY, CheZ, CheR, and CheB. Once excited by a chemical attractant the bacteria will respond to the gradient levels of the chemicals. If it is a rich area then it will move less and go into a prestimulant mode. The chemotaxis is quite a sophisticated system involving three control levels, lateral, motor and metabolic (Grebe, Stock 1998). Suppose we wish to see how the bacteriophage and its host might respond to different situations we could simulate the results using a programme based on biorhetorics. Below I have pared down classical rhetoric to its bare essentials.

\subsection{Rhetoric}

Rhetoric can be defined as the art/techne of persuasive eloquent speech/writing. 


\subsection{Rhetorical situation (Kairos)}

I have reduced the kairotic situations of legal, political, and ceremonial to the following. Usually before the composition of a speech there is an apriori situation that can be reduced to the following: audience $(A)$ is at position $(Y)$. The position $(Y)$ can also be a course of action, i.e., $(A)$ is doing $(Y)$. Biorhetorics operates in a similar manner to argumentation theory the movement is from agreed premises to a conclusion.

\subsection{Rhetor}

The rhetor or orator is the rhetorical agent. He/she/it uses rhetoric to persuade $(A)$ to move from position $(Y)$. The "move" corresponds to that used in dialectical argumenation and in argumentation theory.

\subsection{Audience}

The audience is the listener or receiver of the speech. This could be the audience as an individual, as a group, or as a set of groups. There is an indirect audience $(I)$ who might also be involved in the rhetorical situation. For example $(A)$ is hitting $(Y)$ a $\operatorname{dog}(I)$.

\subsection{Argument}

From the above we can create a simple diagram.

$$
(R)---->(A)====>(Y) \text { or }(Z)
$$

The rhetor argues with the audience trying to persuade them to stop hitting the dog. We can see that in geometrical terms the force of the argument $(X)$ will be the equal to the force required to move the audience from position or course of action $(Y)$ to the desirable position (Z). It follows that the argument can be measured in the success of a probable outcome. Since the argument proper is measurable in these terms, it also follows that topics and the macro/microstructural elements of rhetoric such as figures and tropes can evaluated similarly. 


\subsection{Ethical teleology}

Aristotle instituted a good as the teleology of the argument.

$$
\begin{aligned}
& (R)---->(A)====>(Y) \text { or }(Z) \text { if }(Z) \text { then } A \text { equal or greater than } A \\
& \text { (benefit) }
\end{aligned}
$$

\subsection{Explanation of the terms}

$R$----> $A====>$ from $Y$ to $Z$

$R$ is the rhetor

$A$ is the audience (organism in this case)

$Y$ is the current action or position

$Z$ is the desired or preferable action or position

$X$ is the force (move) of the argument and the distance between $Y$ and $Z$

The force of the ethymetic argument runs along an axis that is equal to the distance between $Y$ and $Z$, in other words we can create an equilateral triangle with one of the sides being $X$. It also follows that the components of the argument created by the rhetor must be evaluated according to the successful outcome, divisible by $X$. So if for example that in the argument we used a simile, "white as snow", that particular simile would be weighted according to a probable success and in terms of actual success. If we were to use this with classical rhetoric we would evaluate the various hierarchies and perhaps use matrices drawn from informatics to display the values of each hierarchy. A particular branch of oratory would have more success than another, and it would be possible given the situation "kairos" to weigh each branch, and indeed sub-division, going down to the microstructural such as the above simile. Given that the "language" or systems of communication of the M13 are different from human and classical rhetoric it is necessary to convert these hierarchies and their components into symbolic relations. In the case of the bacteriophage the language or communication system is chemical. The $M 13$ recognises itself, other bacteriophages, potential host $E$. coli through molecular recognition and reception. One could then identify the chemicals in question and use them as a simple topoi or database to draw upon. The environment and the genomes of the 
two species involved provide the kairos and decorum. At its simplest the simile is to do with the following relation:

$A$ has the same degree of something as $B$.

White is an attribute of snow. It is not snow.

(W/A)S. White is an attribute of $A$ to the power of $S$.

If we say that her face was white as snow, then (white/face) snow would be the order of relations. If we could measure the whiteness of snow according to a spectrometer or colour calibration system, we could gain, e.g., (white/face) 32888. The M13 and the E. coli would not relate to whiteness but perhaps the degree or concentration of the pheromone produced by the other organism and to ones that are either opposite or similar in composition. We could translate a simple functional biorhetorical argument into their "system" of communication so as to meet the criteria of rhetoric that the speech be between two parties of equal or shared cognitive abilities.

\subsection{Audience dynamics and boids}

As in the case of Chaim Perelman's seminal work on new rhetoric (Perelman 1982; 1984), the audience is central to the theory of biorhetorics, and especially its dynamics when we think of animal communication studies and the distribution and decoding of signals and their systems. Audience dynamics is especially important in biorhetorics as there can be a great divergence in the responses ranging from an individual member of a species, responses of a family, a clan, a large group, and millions. If we watch the performance of an orator we will note that he/she picks up on the subtle changes in the audience's mood, and will target one member who is more susceptible or more powerful in the audience. If it is in front of a king, the mood of the king will have a profound effect on his subjects: if he laughs he will cause others to do so. The dynamics of large audiences requires the technology used in flocking so as to anticipate a possible response in an audience. The boid technology used in the cinema industry but based on zoological experiments could be part of the programme. While it is somewhat easier to identify the movement and responses of mammals and other higher order organisms, it would be difficult to see how this can be done with minute organisms like the M13. Yet even here we can say the position and awareness of an individual M13 or cluster of $M 13 \mathrm{~s}$ in one position will differ from those further away. 
Distance is an important factor in the dynamics of microorganisms which require molecular reception to detect each other and their hosts. Moreover, the composition of an individual M13 can differ in age etc as well. Given essential information regarding the $M 13$ and its host we could then run a programme that could simulate responses in many different situations and with different audience numbers.

\subsection{Probability and enthymemetic reasoning in functional rhetoric}

In the development of a biorhetorical argument, one realises that as Plato and most rhetoricians knew, the argument is grounded in the probability. If I am delivering a speech to an audience of three hundred and one journalists about the need for greater control over recycling and follow up, where exactly do those plastic bottles go? I am not likely to be successful if I use technical language with them unless they are specialists, but at the same time I must take into account that among those three hundred and one journalists one or more is going to be a specialist. Each time I say something I get a feedback in terms of applause or sounds of approval, disapproval, or at the end by the nature of questions asked. This would be the initial feedback, but the actual success could be measured by if the press help change the minds of the government and public at large, since the media plays such a profound role in shaping policies. Speechmakers and those in government have spent millions refining their pr campaigns and speeches. Every detail is important; witness how Margaret Thatcher and Hilary Clinton groomed themselves, adopted different stances, and modified their body language and their voices. This can be done in a programme that works on probability modelling. Simulating the stimuli and responses in communication acts, and rhetorical acts. In animal communication several methods are employed that use Bayesian probability for an array of modalities (visual, auditory, chemical, and electric, measuring the pay-off and benefit of these modalities. I believe that biorhetorics can organise several approaches at once, structure the simulation so that it will provide researchers with better models of how an organism reacts to different sets of situations.

The use of enthymemetic reasoning is dialogical and dynamic, requiring the organism to supply the missing term, by doing so we can test the cognition and communication systems of the organism, as well 
as measure the outcome of different interventions. Science by the way is not descriptive, but interventionist. The scientist who claims to be a dispassionate observer of phenomena forgets that the act of observation requires the marshalling and selection of facts.

\section{Argumentation theory and biorhetorics}

Biorhetorics like Toulmin's argumentation theory (Toulmin 1958) is unashamedly cross disciplinarian. But its model differs in many aspects from Toulmin's six-point model that is legalistic in nature, as is Chaim Perelman's 'new rhetoric'.

$\begin{array}{ll}\begin{array}{l}\text { Toulmin } \\ \text { data }\end{array} & \begin{array}{l}\text { classical rhetoric/biorhetorics } \\ \text { claim }\end{array} \\ \text { same (topoi) (part of } X \text { ) } \\ \text { warrant } \\ \text { backing } & \text { proofs/figures of reasoning (part of } X \text { ) } \\ & \begin{array}{l}\text { arête or nobility of the speaker } \\ \text { in biorhetorics the credentials of the speaker }\end{array} \\ \text { rebuttal } & \begin{array}{l}\text { enthymemetic reasoning takes into account of the } \\ \text { audience biorhetorics includes a feedback loop } \\ \text { the force of the argument is changed accordingly } \\ \text { included in the counter response calibrated } \\ \text { to take into account of success of the argument }\end{array}\end{array}$

The elements of both Toulmin's and Perelman's argumentation theories are the result of focusing on forensic oratory and seeped in quasi legal notions of self, tests of competency, agency, responsibility, and are expressly concerned with humans, who have minds, property and a sense of justice. One might claim the same for other life forms, and indeed one does uphold rights to self determination, life etc., for a whole variety of animals, but this is done within human terms, and the starting point is not at the level of the organism in question, which has a different instinctual concept of what this or that is. Moreover like those working in cognition studies, those in argumentation theory studies are operating from a privileged position even if they have reduced classical rhetoric to six points or so, they require the rhetor and audience to be reasonable, and to have a mind, which many life forms cannot be and do not have. A bacteriophage cannot even be 
allowed through the back door of emotionalism because it simply does not have emotions and is so small that it cannot mimic human emotions or moods. Argumentation theory is an attempt at formalising rhetoric, yet wishes to distinguish itself from formal logic which it sees as being impersonal and rooted in strict mathematical rules, it has also sought a path away from Aristotle's teleology of a good, instead it nestles uncomfortably between rights derived from jurisprudence and general ethics. Biorhetorics seeks more rigour, using inferences and modes of calculation drawn from the life sciences, it uses science and mathematics, and the good/benefit aimed at is one, which is useful for the rhetor in changing the audience's position. The laws of rhetorical competency are based upon the knowledge of the audience in question, and do not discriminate in terms of whether it can pass this or that cognitive test or the "reasonable man" test of law.

\section{Conclusion}

In the writing up of this paper I have taken time to consider some of the philosophical ramifications of biorhetorics as a new methodology and approach. If we consider the simile above "white as snow" and the "German declarative sentence 'Der schnee is weiss"" (Quine 1986: 1) we can see that the simile has some correspondence to the nature of the truth predicate in Tarski's paradigm and its relation to "real snow",

'Snow is white' is true if and only if snow is white (Quine 1986: 12).

The problem of truth and meaning has preoccupied philosophers and logicians for a long time, it was one that William Ockham dealt with in the Middle Ages. For our purposes the problem of truth is one that is connected to the drive to reduce and formulate. If we decide that we can do away with this proposition or that statement it makes it easier to apply logic in other fields, and of course greatly benefits computer operations. Whether truth is in the predicate, the parts or outside the speech marks seems to be one of those questions that philosophers of logic love, yet seems easily resolvable by the layman. "Snow is white" is language and snow is white is reality. But then we come to the problem of what is reality and is that reality predicated by language and so forth. Whatever the outcome of looking into the truth of such statements, it is clear that the relationship of a simile to the "real snow" is one of amplification, or extension, and greater than the rela- 
tionship of a declarative statement to snow. The difference between logic and rhetoric can be characterised in spatial terms; rhetoric occupies greater conceptual and perceptual space than logic. From this we could conclude that logic in its general form is more manageable than rhetoric. If we apply William Ockham's razor, the outcome would be the same. However, if we consider the nature of science itself and mathematics, and look how problems are solved, we see that the discovery of the double helix and the solution to Fermat's Last theorem were done with the aid of mixed modelling, and if we visualised these solutions as streets, then the architecture would higgedly-piggedly and completely heterogeneous. The approach I have in mind is accommodating; it starts with the questioning element of a hypothesis, how, what if, etc. The question is the situation or kairos, which is used as the basis of argumentation modelling. Let us take malaria. First we can decide upon the audience. Is it to be Man, the Mosquito, or the Plasmodium? What is the problem? Define the kairos. Seek out the UmWelt and the environmental and epistemological boundaries of the species involved. If we decide upon the plasmodium then we can draw upon its genome, which has been completed, and our knowledge of its life cycle, modes of movement and communication through that life cycle. Here we can decide at what "age group or stage" we are interested. We can consider the indirect audience on a cellular level or below to include the gut of the mosquito and the humans involved. Using the basic biorhetorical argument we can then construct an argument at the level of classical rhetoric, one at a higher level comprehensible to ourselves, this is the working model of argumentation, from this we derive a functional architecture and translate using symbolic rhetoric the various data derived from the science of the day, and then create the species specific rhetoric. The argument can be formulated thus in a sophisticated manner, one, which could have a human audience in mind. This is like a draft or model. Then onto the functional which is strictly mathematical in nature and programmable. Each of the terms and components of the argument would be weighted according to the responses or results of the research. As stated above one could using data from the plasmodium and other species run a simulation of the probable outcomes and responses given this or that stimuli. Biorhetorics represents a comprehensive methodology that is firmly based on strict rational approaches, but allows for the variables within each organism's Umwelt whether they be human or bacteria. 
Biorhetorics is a tripartite rhetoric derived from classical rhetoric, beginning with functional rhetoric and it moves onto symbolic rhetoric, and finally arrives at a species-specific rhetoric. It does not represent a closed door. It is a project. The above rather than a definitive introduction should be seen as an approach. As can be seen by the process of refining the terms, definitions and scope of biorhetorics, it is interdisciplinarian. The applications of biorhetorics are innumerable. One can see it used in conflict of interest situations, such as the encroachment of land, either by man, or say the polar bear. One can use it in situations where anthropomorphism is evident, as in bear ceremonialism or the daily exchanges between humans and domestic pets and in animal behaviour studies, especially communication. For the development of new AI models. In medicine in combating diseases. In genetics, if we move the goalposts to allow for proto-life structures, we can see the issues and problems at the molecular level. As I stated before, biorhetorics is not rhetoric/s of biology, it should stand on its own, and take its place alongside biosemiotics, bioinformatics and cybernetics.

\section{References}

Aristotle 1991. The Art of Rhetoric. (Translated by Hugh C. Lawson-Tancred.) London: Penguin.

Austin, John L. 1962. How to Do Things with Words. Oxford: Clarendon Press.

Bownds, M. Deric 1999. The Biology of Mind: Origins and Structures of Mind, Brain, and Consciousness. Bethesda: Fitzgerald Science Press.

Bradbury, Jack W.; Vehrencamp, Sandra L. 1998. Principles of Animal Communication. Sunderland: Sinauer Association.

Buchler, Justus (ed.) 1955. Philosophical Writings of Peirce. New York: Dover.

Cann, Alan J. 2001. Principles of Molecular Virology. 3rd ed. London: Academic Press.

Darwin, Charles 1872. The Expression of the Emotions in Man and the Animals. London: John Murray.

Eemeren, Frans H. van; Grootendorst, Rob; Kruiger, Tjark 1987. Handbook of Argumenation Theory. Dorecht: Foris Publications.

Gilbert, Michael A. 1997. Prolegomenon to a pragmatics of emotion. Proceedings of the Ontario Society for the Study of Argumentation. St Catherine's: Brock University.

- 1999. Language,Words and Expressive Speech Acts. In: Eemeren, Frans van; Grootendorst, Rob; Blair, J. Anthony; Willard, Charles A. (eds.), Proceedings of the Fourth International Conference of the International Society for the Study of Argumentation. Amsterdam: Sic Sat, 231-234. 
Gjertsen, Derek 1989. Science and Philosophy: Past and Present. Harmondsworth: Penguin Books.

Grebe, Thorsten W.; Stock, Jeff 1998. Bacterial chemotaxis: The five sensors of a bacterium. Current Biology 8: r154-r157.

Groupe $\mu$ (Dubois, J; Edeline, F.; Klinkenberg, J.-M.; Minquet, P.; Pire, F.; Trinon H.) 1982. Rhétorique Générale. Paris: Editions du Seuil.

Hallowell, Alfred Irving 1926. Bear ceremonialism in the northern hemisphere. American Anthropologist (New Series) 28(1): 1-175.

Hauser, Marc D. 1996. The Evolution of Communication. Cambridge: MIT Press.

Kull, Kalevi 2001. A note on biorhetorics. Sign Systems Studies 29(2): 693-704.

Lee, Jill [Guard-Petter, Jean] 2000. New Salmonella finding — inter-bacterial communication! Agricultural Research Magazine 48(1): 10-11.

Lorenz, Konrad 1966. On Aggression. London: Methuen.

- 1970. Trois essais sur le comportment animal et humain. (Trans. by C. Fredet and P. Fredet.) Paris: Editions du Seuil.

Malacinski, Georges M.; Freifelder, David 1998. Essentials of Molecular Biology. (3rd ed.) Boston: Jones and Bartlett Publishers.

McFarland, David 1981. The Oxford Companion to Animal Behaviour. Oxford: Oxford University Press.

Molinié, George 1992. Dictionnaire de rhétorique. Paris: Librairie Générale Française.

Perelman, Chaim 1982. The Realm of Rhetoric. London: University of Notre Dame Press.

- 1984. The new rhetoric and the rhetoricians: Remembrances and comments. Quarterly Journal of Speech 70: 188-196.

Perelman, Chaim; Olbrechts-Tyteca, Lucie 1951. Act and person in argumentation. Ethics 61: 251-269.

Plato 1956. Protagoras and Meno. (Translated by W. K. C. Guthrie.) Penguin.

- 1971. Gorgias. (Translated by Walter Hamilton.) Penguin.

Primio, Franco di; Müller, Bernd S.; Lengeler, Joseph W. 2000. Minimal cognition in unicellular organisms. In: Meyer, J.-A.; Berthoz, A.; Floreano, D.; Roitblat, H. L.; Wilson, S. W. (eds), SAB2000 Proceedings Supplement: 6th International Conference on Simulation of Adaptive Behavior: From Animals to Animats. Cambridge: MIT Press, 3-12.

Quine, W. V. 1986. Philosophy of Logic. Cambridge: Harvard University Press.

Reynolds, Craig W. 1987. Flocks, herds, and schools: A distributed behavioral model. Computer Graphics 21(4): 25-34.

- 1993. An evolved, vision-based behavioral model of coordinated group motion. In: Meyer, J. A.; Roitblat, H. L.; Wilson, S. W. (eds.), From Animals to Animats 2: Proceedings of the Second International Conference on Simulation of Adaptive Behavior (SAB92). Cambridge: MIT Press, 384-392.

Searle, John 1969. Speech Acts. Cambridge: Cambridge University Press.

Sebeok, Thomas A. 1972. Perspectives in Zoosemiotics. The Hague: Mouton.

Toulmin, Stephen 1958. The Uses of Argument. Cambridge: Cambridge University Press.

Uexküll, Jakob von 1965. Mondes animaux et monde humain, suivi de Théorie de la signification. (Traducion et presentation de Philippe Muller.) Paris: Denoël.

- 1973 [1928]. Theoretische Biologie. Frankfurt am Main: Surhrkamp Verlag. 


\section{Биориторика: введение в прикладную риторику}

Статья представляет собой введение к новой отрасли науки - биориторике. Биориторика является прикладной формой риторики, которая образовалась из классической риторики, прежде всего - аристотелевской. Автор иллюстрирует этапы развития, необходимые для возникновения риторики специфичекого вида: (1) формализация риторики с образованием функциональной риторики; затем (2) редуцирование этого к символической риторике, которую можно использовать вместе с данными, собранными об Umwelt (а также о геноме) организма, чтобы разработать (3) риторику специфического вида. В ходе дискуссии о природе биориторики автор отличает ее от теории аргументации и от риторики биологии, полагая, что биориторика должна стоять в одном ряду с такими отраслями науки как биосемиотика, теория информации, теория игр и др.

\section{Bioretoorika: Sissejuhatus rakenduslikku retoorikasse}

Artikkel on sissejuhatuseks uuele valdkonnale — bioretoorikale. Bioretoorika on rakenduslik vorm retoorikale, mis kujunes välja klassikalisest, eelkõige Aristotelese retoorikast. Illustreeritakse uurimistöö etappe, mis on vajalikud liigispetsiifilise retoorika loomiseks: (1) retoorika formaliseerimine, luues sellega funktsionaalse retoorika; (2) viimase redutseerimine sümboliliseks retoorikaks, mida saaks kasutada koos organismi omailma (ja samuti genoomi) kohta kogutud andmetega, et välja töötada (3) liigispetsiifiline retoorika. Artiklis tuuakse näiteid hiljutistest uuringutest bakterite ja viiruste kommunikatsiooni vallast, et demonstreerida bioretoorika võimalusi. Arutledes bioretoorika olemuse üle, eristab autor seda väiteteooriast ja bioloogia retoorikast, ning paigutab bioretoorika kõrvu selliste eluteaduse aladega nagu biosemiootika, informatsiooniteooria, mänguteooria, jt. 